\title{
Parents' Roles in Shaping Early Adolescents' Occupational Aspirations
}

\author{
Kathleen M. Jodl, Alice Michael, Oksana Malanchuk, \\ Jacquelynne S. Eccles, and Arnold Sameroff
}

\begin{abstract}
Relations among dimensions of parenting and adolescents' occupational aspirations were examined in two specific domains: academics and sports. The sample consisted of 444 seventh graders, with approximately equal numbers of African American and European American males and females, from two-parent nondivorced families. Multiple measures were used as indicators of parents' values and behaviors, youths' values and beliefs, positive identification with parents, and adolescents' occupational aspirations. In the academic domain, parents' values predicted youths' values directly rather than indirectly through their behaviors. In contrast, fathers' behaviors mediated the relation between parents' and youths' values in the sports domain. Positive identification was directly related to adolescents' values (especially about academics); however, positive identification did not moderate the transmission of values from parent to child in either domain. Parents' values predicted adolescents' occupational aspirations via both direct and indirect pathways. Similar results were obtained for African American and European American males and females. These findings highlight the potential role of parents as socializers of achievement-related values, and, ultimately, adolescents' occupational visions of themselves in the future.
\end{abstract}

\section{INTRODUCTION}

Both theory (e.g., Eccles, 1993; Ginzberg, 1972; Holland, 1985; Roe, 1957; Super, 1990) and empirical research (e.g., Eccles, Barber, \& Jozefowicz, 1998; Fitzgerald \& Betz, 1983; Mortimer, Lorence, \& Kumka, 1986; Penick \& Jepsen, 1992; for review, see Schulenberg, Vondracek, \& Crouter, 1984) highlight to varying degrees the family's role in influencing children's occupational aspirations. Roe's (1957) theory, for example, focuses on the importance of the early parent-child relationship in career development, whereas Holland (1985, p. 93) emphasizes the environments that parents create for their offspring such that "types produce types." The developmental theory of Super (1990) also recognizes the family as a source of influence on self-concept and career maturity. Eccles' expectancy-value model emphasizes parents as role models, sources of reinforcement, and providers of information, resources, and opportunities for their children (Eccles, 1993).

Evidence from the empirical literature also lends support for the primacy of parents in shaping adolescents' career aspirations (e.g., Eccles, 1993; Grotevant \& Cooper, 1988; Mortimer et al., 1986; Schulenberg et al., 1984). Much of the empirical focus has been on structural features of the family, such as socioeconomic status or parental occupation, rather than process variables such as parents' socialization practices (Grotevant \& Cooper, 1988; Schulenberg et al., 1984). A consistent finding reported in the sociological literature is that parents' level of education and occupa- tional status are associated with children's educational and occupational aspirations (e.g., Fitzgerald \& Betz, 1983; Hannah \& Kahn, 1989; Hill \& Duncan, 1987; MacKay \& Miller, 1982). A limitation of these status-attainment models is that they fail to yield explanations beyond "SES begets SES." Therefore, researchers have shifted their focus to the exploration of family processes (e.g., parents' role modeling, attitudes, and behaviors) that might contribute to the development of adolescents' occupational identities and choices (Eccles et al., 1998; Grotevant \& Cooper, 1988; Mortimer et al., 1986; Penick \& Jepsen, 1992; Schulenberg et al., 1984).

The present study investigates the pathways linking parental values, beliefs, and behaviors to adolescents' occupational aspirations. Relatively little research has examined such family processes in achievementrelated domains other than academics (Wigfield \& Eccles, 1992). We chose to focus on the role of parents in two achievement-related domains-academics and sports-using an ethnically diverse sample of early adolescents and their parents. Although identity consolidation typically is not achieved until late adolescence or young adulthood, early adolescence represents a potentially critical period when individuals' emerging visions of themselves begin to influence occupational planning and course enrollment decisions (Eccles et al., 1998; Super, 1990). As significant adults

(C) 2001 by the Society for Research in Child Development, Inc. All rights reserved. 0009-3920/2001/7204-0019 
in the adolescent's world, parents may be particularly salient during this period of time as youth start to explore different conceptions of who they are and who they want to be.

Parents' Achievement-Related Beliefs versus Achievement-Fostering Behaviors

Parents potentially influence adolescents' activity choices and occupational identities through their roles as interpreters of reality and providers of experiences for their children (see Eccles, 1993). First, as a filter for their child's experiences and abilities, parents may impact their adolescents' self-perceptions and task values across achievement-related domains. Parents' interpretation of reality as expressed through their beliefs and perceptions about their child and the value of certain activities may be communicated in both subtle and overt ways. For instance, parents might implicitly encourage their children to join the soccer team by watching World Cup soccer on TV or explicitly tell their children that they are good at sports. The available evidence suggests that such messages do influence adolescents' own beliefs about themselves and the value of various tasks (e.g., Klebanov \& Brooks-Gunn, 1992; Scanlan \& Lewthwaite, 1985), as well as their educational and vocational choices (e.g., Eccles et al., 1998; Wilson \& Wilson, 1992). Several investigators have documented a positive association between parents' perceptions of their children's academic skills and adolescents' selfconcepts of these abilities (Alexander \& Entwisle, 1988; Eccles, Adler, \& Kaczala, 1982; Miller, Manhal, \& Mee, 1991). Moreover, parents' expectations for their children's eventual educational attainment have been related to children's own educational expectations and self-concepts, as well as to their actual academic performance (Halle, Kurtz-Costes, \& Mahoney, 1997; Phillips, 1987). Although they are limited, similar findings highlighting the importance of parental values and beliefs have been reported with respect to youths' athletic abilities (Eccles \& Harold, 1991; Trent, Cooney, Russell, \& Thornton, 1996) and their expectations for success and enjoyment of sports (Scanlan \& Lewthwaite, 1985, 1986).

Second, parents can foster children's interests and activity choices through the experiences they provide in the home and their specific parenting practices. That is, parents may translate their values and beliefs into actions and thereby transfer them to the child simply by engaging in different activities (Eccles, 1993). Parents' who read to their children, for example, send a clear message regarding the value of academic pursuits, as compared with the parents who use their spare time to coach their children's Little League team. In this way, specific parenting behaviors may affect adolescents' activity preferences, their beliefs about themselves, and, ultimately, their educational and occupational choices.

Parents' involvement with their children has been shown to impact achievement motivation and behavior in a number of studies (e.g., Dauber \& Epstein, 1993; Eccles, Wigfield, \& Schiefele, 1997; Scanlan \& Lewthwaite, 1986; Stevenson \& Baker, 1987). Specifically, parenting behaviors associated with children's academic achievement include parenting styles, verbal interaction, book reading, helping with homework, and school involvement (Dauber \& Epstein, 1993; Muller \& Kerbow, 1993; Stevenson \& Baker, 1987; Trusty, 1996; Wilson \& Wilson, 1992). Although much of this research has focused on academic competence, there is reason to believe that parents' behaviors also matter for other achievement domains such as athletics. For example, in a sample of young athletes, Hoyle and Leff (1997) found that parental support and involvement was positively related to adolescents' activity enjoyment and the value they placed on doing well in sports.

Parental Identification as a Moderator of Adolescents' Achievement-Related Beliefs

A potential moderator of the messages that parents provide to their children about achievement-related values and beliefs is the quality of the parent-child relationship. Adolescents should be more likely to internalize parental values and beliefs if they experience a warm, supportive parent-child relationship and view their parents as positive role models (Mortimer et al., 1986). Although few studies have investigated this question directly, support for this perspective can be derived from the literature on educational achievement and career development. Parenting style (Dornbusch, Ritter, Leiderman, Roberts, \& Fraleigh, 1987), communication between parents and children (Forehand, Long, Brody, \& Fauber, 1986; Masselam, Marcus, \& Stunkard, 1990), and autonomy and relatedness within the parent-child relationship (K. Bell, Allen, Hauser, \& O'Connor, 1996) all predict adolescent behavior and performance in school. Aspects of the parent-child relationship that have been investigated with respect to career development include emotional closeness (e.g., Lunneborg, 1982; Mortimer \& Kumka, 1982) and identification and perceived similarity to parents (e.g., Jackson \& Meara, 1977; Ridgeway, 1978). For example, Mortimer et al. (1986) found that an emotionally close father-son relationship fostered the development of self-competence, 
work involvement, and occupational values. Similarly, higher levels of emotional support and attachment to parents have been linked to greater career maturity and progress toward committing to a career among high school and college students (Blustein, Walbridge, Friedlander, \& Palladino, 1991; Palmer \& Cochran, 1988). Parental identification has been associated with higher levels of educational achievement, occupational status, and vocational aspirations among older adolescents and young adults alike (e.g., Jackson \& Meara, 1977; Lunneborg, 1982). Taken together, these findings suggest that certain affective dimensions of the parent-child relationship might modify the messages that parents transmit to their children, children's receptivity to these messages, or both.

\section{Adolescents' Achievement-Related Beliefs} as Mediators of Occupational Aspirations

Individual differences in occupational aspirations are assumed to be influenced by one's self-perceptions and subjective task values (Eccles et al., 1983; Holland, 1985; Mortimer et al., 1986; Super, 1990). Expectations for success (or failure), self-perceptions of ones' ability and activity value, and personal efficacy have been linked to a variety of achievement-related behaviors in both academics and sports (Betz \& Hackett, 1986; Deeter, 1990; Eccles et al., 1998; Eccles \& Harold, 1991; Hollinger, 1983; Mortimer et al., 1986; Roberts \& Duda, 1984). Ratings of academic self-efficacy and perceived activity value have been associated with persistence and performance in the classroom, course enrollment decisions, and vocational aspirations and choices (Betz \& Fitzgerald, 1987; Betz \& Hackett, 1986; Eccles et al., 1983; Eccles et al., 1998; Hollinger, 1983; Lent, Brown, \& Hackett, 1994). The work of Mortimer and colleagues (Mortimer et al., 1986), for example, suggests that at least among young men, self-image and attitudes toward work influence subsequent occupational outcomes. Research specific to math achievement has yielded a consistent positive relation between self-perceptions of math abilities and enrollment in advanced math courses as well as aspirations to enter math-related careers such as engineering or computer science (Eccles et al., 1983; Hollinger, 1983). Similar findings have been reported with respect to sports (e.g., Eccles \& Harold, 1991; Weiss, 1987).

\section{Aims of the Present Study}

The primary objective of this study was to examine the direct and indirect pathways linking various aspects of parenting to occupational aspirations in an ethnically diverse sample of early adolescents grow- ing up in nondivorced families. Research investigating these processes typically has used middle-class, European American samples or has confounded race with class by comparing middle-class Whites with poor African Americans (Halle et al., 1997). The current sample of African American and European American families is unique in that both subgroups represent comparable populations of families, normally distributed in terms of socioeconomic status.

The general conceptual model presented in Figure 1 summarizes the major dimensions of parenting in relation to youth occupational aspirations for both academics and sports. An assumption inherent in this model is that parents influence children's behavior rather than vice versa. We recognize that relations among these variables may be bidirectional or explained by "third variables" not included in the model. Alternatively, the effects may be partially child driven (R. O. Bell, 1979). For example, parents' perceptions of their children's abilities may be influenced by the adolescents' own self-perceptions and the value they place on various activities. Another possibility is that youths' values and beliefs mediate the impact of parents' values and beliefs on their specific parenting behaviors. Unfortunately, it is not possible to disentangle the direction of effects because of the cross-sectional nature of the data. Nevertheless, on the basis of theory and the empirical literature, parental factors were posited to play a key role in the development of early adolescents' occupational aspirations.

Three basic hypotheses were examined in this study. First, parents' values and beliefs were expected to be related to youths' values and beliefs directly as well as indirectly, via their specific parenting practices. That is, parents' roles as both interpreters of reality and providers of experiences were expected to

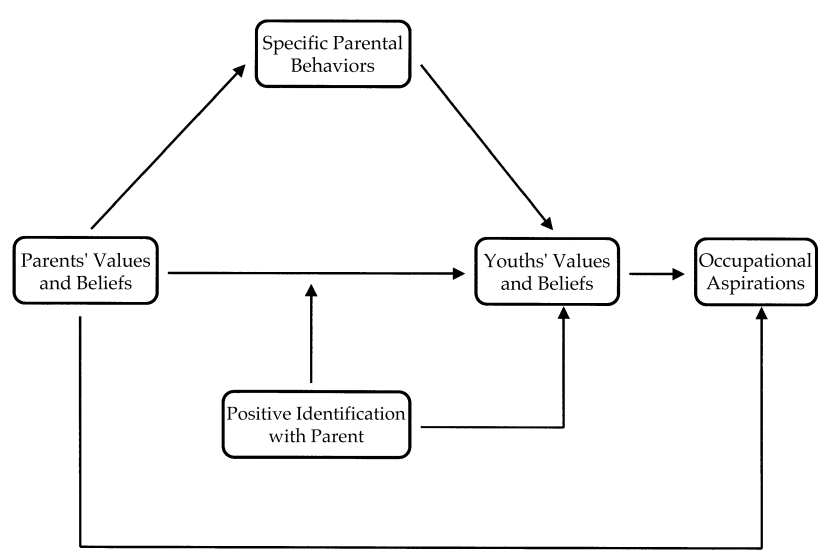

Figure 1 Conceptual model linking dimensions of parenting to adolescent occupational aspirations. 
be important predictors. As interpreters of reality, parents who value academics or sports should have children who value these activities. As providers of experiences, parents should translate their values and beliefs into behaviors that mediate, in part, the relation between parent and youth values. Second, it was hypothesized that positive identification with one's parent would moderate the association between parents' and youths' values and beliefs. Adolescents should be more likely to internalize parental values if they view their parents as positive role models and feel close to them. Third, it was anticipated that parents' values and beliefs would predict adolescents' occupational aspirations directly and indirectly through youths' own values and beliefs. Parents' values were expected to be positively associated with adolescents' occupational aspirations, and that the relation between parents' values and youths' occupational aspirations was expected to be partially mediated by adolescents' values and beliefs.

The bulk of the research examining parents' role in shaping adolescents' occupational aspirations has been limited to the academic domain. Relatively little is known about how parents, especially fathers, socialize youths' values, beliefs, and aspirations in other achievement domains such as sports (Wigfield \& Eccles, 1992). To address this issue, two domain-specific models - an academic and a sports model were developed (see Figure 1). Occupational aspirations were defined in the academic model based on the clarity and consistency of the adolescents' goals around professional careers (e.g., doctor, lawyer, architect). This model is referred to as the academic model because values, beliefs, and behaviors specific to academic achievement are assumed to be the salient mediators of individuals' aspirations for professional careers. In the sports model, occupational aspirations were defined based on adolescents' clarity and consistency around sports careers (e.g., professional baseball or basketball player). Variables in the sports model reflect values, beliefs, and behaviors specific to athletic activities.

\section{METHOD}

\section{Sample}

The sample was part of a large, ongoing longitudinal study of an ethnically diverse county in the midAtlantic region of the United States. The study (Maryland Adolescent Development in Context [MADIC]; Principal Investigators, J. Eccles and A. Sameroff) was designed to examine the influence of social contexts on adolescent development. In 1995, 51\% of house- holds were African American and 43\% were European American, yielding a balanced racial distribution in the county. A stratified sampling procedure was used to obtain a representative sample of families from 23 junior high schools in the area. A total of 1,961 families expressed an interest in the study by signing a form permitting us to contact them. The first 1,500 families contacted were recruited to be study participants, and of these families, 1,498 actually took part in the study at Wave 1 when adolescents were in the seventh grade. Analyses conducted to compare this sample with the larger population of adolescents in the county revealed few differences across a variety of demographic characteristics and academic indicators. This sample was somewhat wealthier and more likely to be European American than the larger population sample (Cook et al., 1999).

Because one of the goals of the present study was to compare the results for mothers and fathers, only those seventh graders who were living in nondivorced families and for whom interviews with both biological parents had been obtained were selected $(n=444)$. Excluded from the sample were those families who had not provided information on marital status $(n=358)$, non-divorced families who had not provided complete information on the fathers $(n=187)$, stepfamilies $(n=142)$, single-parent families resulting from separation or divorce $(n=221)$, single-parent families in which the mother never married $(n=82)$, and live-in families in which the mother was cohabiting with a partner $(n=64)$. Analyses comparing the nondivorced families included in this study with the other families revealed no significant differences across a variety of demographic indicators (e.g., parents' educational and occupational status).

The resulting sample included approximately equal proportions of African American and European American males and females; other ethnic groups, including mixed racial categories, were dropped from the analyses because of small group sizes. The average family income for both African Americans and European Americans was $\$ 55,000$ to $\$ 60,000$ per annum. Nearly one half of European American mothers had completed college as compared with one third of African American mothers. European American fathers also were more likely than African American fathers to have a college degree (56\% versus $37 \%$ ). Thus, both groups represented populations of comparable socioeconomic diversity, albeit on the high end when compared with the average American family. These characteristics presented a unique opportunity to study the development of African American and European American adolescents in maximally comparable sociodemographic circumstances. 


\section{Measures}

The data were obtained using face-to-face interviews and self-administered questionnaires collected from the adolescent, mother, and father during the teen's seventh-grade year. Each participant filled out a large battery of self-administered items and answered an additional set of questions administered by trained interviewers in the family home. A broad array of constructs was assessed, including parents' and adolescents' perceptions, values, and attitudes about academic- and sports-related activities, youths' occupational aspirations, and their positive identification with parents.

In the analyses, a combination of measures was used, including both scales and open-ended items. Scale construction was guided by theoretical concerns and factor analyses. The items included in these scales used 4- to 7-point Likert-type scales anchored at the extremes. Many of these items and scales have been used in earlier work by Eccles and colleagues (e.g., Eccles, 1983; Eccles et al., 1989), and thus their psychometric properties and validity are well established (for full details, see Eccles, Wigfield, Harold, \& Blumenfeld, 1993). A few of the scales were new, created especially for this study using open-ended questions. Interrater reliabilities were excellent, with exact agreement among coders greater than $90 \%$. The specific constructs used in this study are described below. Appendix A provides a summary of all measures except occupational aspirations.

Demographic measures and statistical controls. Sociodemographic characteristics of the target adolescents and their families were used as statistical controls. These measures included adolescents' gender $(1=$ male, $2=$ female $)$ and ethnicity $(1=$ African American, 2 = European American), mothers' and fathers' educational level and occupational status, and total family income. As an indicator of academic ability, adolescents' grade point average (GPA) served as a statistical control for the academic model. To determine GPA, an average of grades in the core academic subjects (e.g., English, math, science) was drawn from school records of the adolescents' seventh-grade year using a 5-point scale $(1=$ Failing, $2=\mathrm{D}, 3=\mathrm{C}, 4=\mathrm{B}, 5=\mathrm{A})$.

Occupational aspirations. Measures of occupational aspirations were developed especially for the MADIC sample and reflected this study's primary focus of examining adolescent identity development around occupational choice. Six raters were trained to code adolescents' responses to open-ended questions obtained during face-to-face interviews. Exact agreement among coders ranged from .85 to .96 for these items. Coding began with a standard sociological measure of occupational goals with responses classified using a modified version of the U.S. Census codes. Codes also included references to the self as revealed in open-ended questions concerning how youths imagined themselves as grown-ups, their heroes and admired adults, their possible selves, what they would wish for if they had three wishes, and what they would do if they had a million dollars. Designed to capture the self-image that the adolescent projected into the future, these codes focused as much on structure and process as on content per se. The coding scheme did not include an assessment of how realistic or fantasy based these seventh-grade adolescents' occupational aspirations may have been. It simply reflected the content and clarity of youths' visions of themselves in future occupations. The goal was to identify the types of futures the adolescents imagined for themselves at this point in time as well as how that vision was organized, if at all. By capitalizing on multiple sources of information, such an approach provided a valid and reliable measure of occupational aspirations.

As noted above, occupational aspirations as defined in this study had two main components: the content and the structure of one's future self. For the purposes of this study, the focus was on two content themes: (1) professional occupations that subsumed jobs in the prestigious-white collar (e.g., doctor, lawyer), science/engineering, and miscellaneous specialist (e.g., accountant, architect) categories, and (2) athletic occupations that included sports aspirations (e.g., football or basketball player).

Structure was determined by the organization, coherence, and consistency (i.e., clarity) of the youths' occupational aspirations. For adolescents to be considered clear about their occupational goals, they had to mention them in at least two places on the questionnaire. For example, adolescents might respond with "basketball player" when asked what job they would most like to have in the future and, later in the interview, they might list "becoming a professional athlete" as one of their three wishes. They might also mention Michael Jordan as their favorite hero. By mentioning the occupation at least twice in two separate places on the questionnaire, we could be confident that the adolescents had put some thought into these aspirations. In contrast, adolescents were classified as unclear if their responses were vague and reflected no real interest in the occupation they mentioned; if their responses were conflicted in that their occupational choices were mutually exclusive or clearly antagonistic with each other; or if their responses provided no information at all. Those adolescents who were clear (i.e., consistent) were then dif- 
ferentiated from those who were unclear (i.e., vague, conflicted, or providing no information) in their future conceptions of themselves. Beyond simplicity, this variable was dichotomized because no additional insight was gained by considering different shades of clarity at this age.

The final dependent measures for occupational aspirations were two dichotomous variables that combined both content and structure. In the analyses, adolescents who aspired to a professional career $(39.3 \%)$ were contrasted against all others $(60.7 \%)$; and those who aspired to a sports career $(8.7 \%)$ were contrasted against all others $(91.3 \%)$.

Youths' values, beliefs, and expectations. Three selfreport scales were used as measures of adolescents' values, beliefs, and expectations in the academic domain: (1) self-concept of academic ability, (2) value of education for the future, and (3) educational expectations/aspirations. Developed previously by Eccles and colleagues, these scales possess good psychometric properties including predictive validity (for further details see Eccles, 1983, 1989, 1993). First, the academic self-concept scale included four items that assessed adolescents' perceptions of their academic competence in math and other school subjects relative to their same-age peers. For example, using a 7-point scale, teens responded to "Compared with other kids your age, how well do you do in math?" Second, five items were combined to create a measure of adolescents' valuing of education for the future. This scale was designed to tap how much adolescents viewed school as a pathway for later opportunities in life. Using a 5-point Likert-style scale, adolescents responded to statements such as "I have to do well in school if I want to be a success in life." Third, a composite of two items ("How far will you actually go in school?," "How far would you like to go in school?") was used to measure adolescents' expectations and aspirations for their future educational attainment. Cronbach's $\alpha$ s were .78, .69, and .83 for academic selfconcept, value of education for the future, and educational expectations / aspirations, respectively.

In the sports domain, the average score of three items was used as an indicator of adolescents' selfconcept of their athletic ability and the value of sports. Using a 7-point scale, adolescents were asked to rate their ability and performance in sports relative to their same-age peers (e.g., "Compared with other kids your age, how well do you do in sports?"). They also responded to the question, "Compared with other kids your age, how important are sports to you?" ( $1=$ much less, $7=$ much more $)$. Developed by Eccles and colleagues (see Eccles et al., 1993), these items have good predictive, face, and construct valid- ity. Cronbach's $\alpha$ for this scale was .88. Parallel scales were not available for youths' athletic expectations / aspirations and the value of sports for the future.

Parents' values, beliefs, and expectations. Three scales were used to measure mothers' and fathers' values and beliefs in the academic domain: (1) chances for positive youth outcomes, (2) educational expectations/aspirations for youth, and (3) perceptions of youth's academic ability. As above, these scales were derived from the work of Eccles and associates, and their construct and predictive validity are well established (Eccles, 1983, 1989). First, the chances for positive outcomes scale was comprised of three items designed to tap parents' beliefs about their child's future, such as completing college, and finding a stable, well-paying job as an adult. Each parent used a 5 -point scale ( $1=$ very low, $5=$ very high) to answer questions such as, "What are the chances your seventh grader will complete college?" Cronbach's $\alpha \mathrm{s}$ were .81 and .79 for mothers and fathers, respectively. Second, the average score for parents' expectations and aspirations for their child's educational attainment was computed separately for mothers and fathers using two questions that paralleled the youth report (e.g., "How far would you like your child to go in school?"). Cronbach's $\alpha$ s were .73 for mothers and .73 for fathers. Third, each parent responded to four items that assessed their perceptions of their adolescent's academic skills relative to other children's using a 7-point scale anchored at the extremes. Cronbach's $\alpha$ was .89 for mothers and .90 for fathers.

One composite scale and an open-ended question were used as measures of parents' values and beliefs about their child's ability and performance in sports. An average score was computed based on three items in which parents rated their child's athletic competence and the value that they placed on their children's aptitude for sports. Using a 7-point scale, parents responded to questions such as "Compared with other children, how well do you think your child will do in sports?" Cronbach's as were .78 and .77 for mothers and fathers, respectively. Additionally, parents responded to an open-ended item designed to tap their perceptions of their child's athletic talents. Mothers and fathers were asked whether their child had "any special [sports] talents, skills, or interests," and if so, to list these talents. A 5-point scale was created to reflect both the primacy (i.e., first mention) and frequency of sports-related talents mentioned by parents. A higher score on this item was indicative of higher parental ratings of their youth's talent for sports.

Specific parenting behaviors. Parents' involvement in their child's education consisted of mother and father 
reports of their (1) academic activity involvement, (2) instrumental support of academic talents, and (3) involvement in the child's school. First, parents' academic activity involvement was based on an average of two items that asked how often they devoted time to (1) helping their adolescent with homework, and (2) discussing what their adolescent did at school. Parents used a 6-point scale ( $1=$ not at all, $6=$ more than once a day) to answer each question (e.g., "In the last month, how often have you helped your seventh grader do homework or a school project?"). Cronbach's $\alpha$ was .60 for both mother and father scales. Second, a single open-ended question was used to measure parents' instrumental support for their adolescent's academic talents. Parents were given three opportunities to mention ways in which they had helped their child pursue academic talents (e.g., enrolled child in special enrichment programs, praised child, exposed child to educational TV). Based on their responses to this item, a 5-point scale was constructed to reflect the level of parental support for their youth's academic talents $(1=$ no evidence of instrumental support, $5=$ three examples of instrumental support). Third, parental involvement in the youth's school as a classroom volunteer, advocate, or policymaker/evaluator was measured based on the frequency of affirmative responses to four questions (e.g., "Have you done any fund-raising for the PTA this year?"). Cronbach's $\alpha$ is not appropriate for this type of measure.

Three indicators of specific parenting behaviors were used in the sports domain: (1) parents' sports activity involvement, (2) instrumental support of sport talents, and (3) fathers' involvement in coaching. Parents' involvement with their child in athletic activities was based on a single question. Using a 6-point Likerttype scale ( $1=$ not at all, $6=$ more than $1 \mathrm{hr}$ a day), mothers and fathers were asked to report how often they played sports with their seventh grader. As above, an open-ended question was used as a measure of parents' instrumental support of their child's sport talents. Parents were given three opportunities to describe what they had done to help their child improve at their sport talent (e.g., purchase equipment, transport child to practices and games, attend athletic events). A 5-point scale was created based on mothers' and fathers' responses to this item $(1=$ no evidence of instrumental support, $5=$ three examples of instrumental support). In addition, fathers responded to an open-ended question about whether they had participated as a coach or leader for their child's athletic team. A 5-point scale was constructed based on the order and frequency with which fathers mentioned coaching their child in sports.
Positive identification with parent. Youth reports of the degree to which they positively identified with each parent were used as measures of positive identification with mothers and fathers. Using a 4-point scale, adolescents were asked to rate how much they wanted to be like their mother or father when they grew up, and how close they felt to their mother or father. An average score was then computed based on these two items. Cronbach's $\alpha$ was .60 for mothers and .68 for fathers.

\section{RESULTS}

\section{Plan of Analysis}

Intercorrelations among variables are presented in Appendix B. A series of hierarchical linear and binary logistic regressions were conducted to test the pathways linking parents' and youths' values, parenting behaviors, positive identification with parents, and adolescents' occupational aspirations (see Figure 1). Multiple regression was chosen over other methods because it offers a straightforward approach to examining interactions as well as main effects. Logistic regression was employed when the dependent variable was dichotomous. The following general analytic strategy was used to test both domain-specific models.

Behaviors as mediators. First, a series of hierarchical linear regressions was conducted to investigate specific parenting behaviors as mediators of the relation between parents' and youths' values. To test for mediation, three separate regression equations were estimated as delineated by Baron and Kenny (1986): (1) specific parenting behaviors as mediators were regressed on parents' values, (2) youths' values were regressed on parents' values, and (3) youths' values were regressed on both parents' values and specific parenting behaviors. Mediation is established when a significant relation between parents' and youths' values is reduced by controlling for specific parenting behaviors. The effects of GPA and other significant demographic variables were controlled for by entering them first into the equations.

Positive identification as moderator. A second set of hierarchical regression analyses examined positive identification with parents' as a moderator of the relation between parents' and youths' values. Using youths' values around academics or sports as the dependent variables, parent values and beliefs were entered into the equation as a block after controlling for GPA and other significant demographic variables. Positive identification with the parent was entered next, followed by a final block comprised of interaction terms (e.g., Positive Identification $\times$ Educational Expectations/Aspirations). 
Pathways to aspirations. Finally, a set of logistic regression analyses investigated the role of youths' values as a mediator of the relation between parents' values and adolescents' occupational aspirations. In this instance, mediation would be established if parents' values no longer significantly predicted occupational aspirations once youths' values were entered simultaneously into the regression equation. As before, the effects of GPA and other significant demographic variables were controlled for by entering them first into the equations.

All analyses were conducted separately for mothers and fathers using the full sample of intact two-parent families. Subgroup comparisons also were conducted within gender and race (i.e., African American boys, African American girls, European American boys, and European American girls). Results from these analyses were not presented, however, because a similar pattern of relations was observed across subgroups. (Results from the subgroup analyses can be obtained from the first author.) Findings are presented first for the academic model and then for the sports model.

\section{Academic Model}

Our first research aim addressed the question: Do parents' values and beliefs directly predict youths' values and beliefs about academics, or do parents indirectly influence their children's beliefs via their specific behaviors? A formal test of mediation was un- necessary because analyses revealed no significant associations between mothers' and fathers' academic values and their specific parenting practices (e.g., involvement in the child's school, instrumental support of academic talents). In addition, parents' specific behaviors were not consistently linked to adolescents' academic values and expectations. Thus, at this age, parents' academic values and beliefs did not appear to be mediated via specific parenting practices. Rather, parents' values and beliefs directly predicted youths' values and beliefs. (Detailed findings from this set of analyses are available from the first author.)

A series of hierarchical linear regressions was performed to examine positive identification as a moderator of the relation between parents' and youths' values. As depicted in Table 1, no significant interactions were observed for adolescents and their mothers. Nonetheless, significant main effects were observed for maternal values and beliefs, as well as for positive identification. First, mothers who viewed their children as having a greater chance for positive outcomes and who held high educational expectations / aspirations were more likely to have children who valued school as being important for their future. Similarly, higher maternal perceptions of their children's academic abilities were associated with higher academic self-concept in adolescents. Moreover, mothers' educational expectations/aspirations for their children were positively related to higher levels of educa-

Table 1 Predicting Youths' Academic Values from Mothers' Values and Beliefs $(N=406)$

\begin{tabular}{|c|c|c|c|c|c|c|c|c|c|}
\hline \multirow[b]{2}{*}{ Predictors } & \multicolumn{3}{|c|}{$\begin{array}{l}\text { School Important } \\
\text { for Future }\end{array}$} & \multicolumn{3}{|c|}{$\begin{array}{l}\text { Academic } \\
\text { Self-Concept }\end{array}$} & \multicolumn{3}{|c|}{$\begin{array}{l}\text { Expectations / } \\
\text { Aspirations }\end{array}$} \\
\hline & $\beta$ & $R^{2}$ & $\Delta R^{2}$ & $\beta$ & $R^{2}$ & $\Delta R^{2}$ & $\beta$ & $R^{2}$ & $\Delta R^{2}$ \\
\hline \multicolumn{10}{|l|}{ Step 1} \\
\hline Grade point average & $.29^{* * *}$ & & & $.43^{* * *}$ & & & $.12^{*}$ & & \\
\hline Mothers' level of education & -.06 & & & .05 & & & $.15^{\star *}$ & & \\
\hline Family income & $.12^{*}$ & $.10^{* * *}$ & - & .01 & $.20^{* * *}$ & - & $.12^{*}$ & $.08^{\star * *}$ & - \\
\hline \multicolumn{10}{|l|}{ Step 2} \\
\hline Perceptions of academic skills & .08 & & & $.28^{\star * *}$ & & & .09 & & \\
\hline Chances for positive outcomes & $.17^{*}$ & & & .01 & & & .08 & & \\
\hline Educational expectations/aspirations & $.12^{*}$ & $.16^{* * *}$ & $.06^{* * *}$ & .01 & $.25^{* * *}$ & $.05^{* * *}$ & $.33^{* * *}$ & $.21^{* * *}$ & $.13^{* * *}$ \\
\hline \multicolumn{10}{|l|}{ Step 3} \\
\hline Positive identification with mother & $.21^{* * *}$ & $.20^{* * *}$ & $.04^{\star \star *}$ & $.13^{* *}$ & $.27^{\star \star \star}$ & $.02^{* *}$ & $.12^{*}$ & $.23^{\star * \star}$ & $.02^{*}$ \\
\hline \multicolumn{10}{|l|}{ Step 4} \\
\hline $\begin{array}{l}\text { Positive Identification } \times \text { Perceptions of } \\
\text { Academic Skills }\end{array}$ & -.01 & & & .05 & & & -.04 & & \\
\hline Positive Identification $\times$ Chances for & & & & & & & & & \\
\hline Positive Outcomes & .03 & & & -.05 & & & .04 & & \\
\hline Positive Identification $\times$ Educational & & & & & & & & & \\
\hline Expectations / Aspirations & .00 & $.20^{* *}$ & .00 & -.01 & $.27^{* * *}$ & .00 & .00 & $.23^{* * *}$ & 00 \\
\hline
\end{tabular}

Note: $\beta$ weight for variable's entry into equation.

${ }^{*} p<.05 ;{ }^{* *} p<.01 ;{ }^{* * *} p<.001$. 
tional expectations / aspirations among youth. Second, adolescents who strongly identified with their mothers tended to place a greater value on school being important to the future, and to possess higher academic selfconcepts and educational expectations / aspirations independent of their mothers' actual academic values and beliefs. Maternal values accounted for significant changes in $R^{2}$ that ranged from $5 \%$ to $13 \%$, whereas positive identification explained an additional $2 \%$ to $4 \%$ of the variance in the youths' values and beliefs.

A similar (albeit somewhat weaker) pattern of relations was observed in analyses conducted with adolescents and their fathers (see Table 2). Like mothers, fathers who held high educational expectations / aspirations for their adolescents were more likely to have children who valued school as important for their future, and who had high educational expectations/ aspirations for themselves, $\Delta R^{2}=.02$ and .09, respectively. Moreover, higher paternal perceptions of their children's academic abilities were associated with higher levels of academic self-concept in adolescents, $\Delta R^{2}=.04$. In contrast to analyses conducted with mothers, however, positive identification was only significantly related to youths' reports of school being important for the future. In this instance, adolescents who more strongly identified with their fathers viewed school as more important for their future, $\Delta R^{2}=.04$.

A set of logistic analyses addressed whether parents' values predicted adolescents' occupational as- pirations directly or indirectly via youth values. To test this mediational hypothesis, logistic regression analyses were performed using professional career aspirations as the dichotomous dependent variable. When only maternal values and beliefs were entered into the equation, mothers' reports of chances for positive outcomes were positively related to adolescents' aspirations, $\mathrm{B}=.55, p<.05$. When youth values were entered simultaneously with maternal values, however, the relation between maternal reports of chances for positive outcomes and youths' professional occupational aspirations became nonsignificant (see Table 3). As shown, only youths' educational expectations and aspirations significantly predicted professional career aspirations after controlling for the gender and GPA of the adolescent. For each one-unit increase in educational expectations/aspirations, the odds of aspiring to a professional career increased by $81 \%$ or by a factor of 1.81. A comparable set of findings was obtained with adolescents and their fathers (see Table 3). Taken together, these results suggest that the link between parents' values and occupational aspirations is mediated via youths' educational expectations/aspirations.

\section{Sports Model}

In contrast to the academic model, some support was found for the hypothesis that parenting behaviors partially mediated the relation between their

Table 2 Predicting Youths' Academic Values from Fathers' Values and Beliefs $(N=406)$

\begin{tabular}{|c|c|c|c|c|c|c|c|c|c|}
\hline \multirow[b]{2}{*}{ Predictors } & \multicolumn{3}{|c|}{$\begin{array}{l}\text { School Important } \\
\text { for Future }\end{array}$} & \multicolumn{3}{|c|}{$\begin{array}{l}\text { Academic } \\
\text { Self-Concept }\end{array}$} & \multicolumn{3}{|c|}{$\begin{array}{l}\text { Expectations / } \\
\text { Aspirations }\end{array}$} \\
\hline & $\beta$ & $R^{2}$ & $\Delta R^{2}$ & $\beta$ & $R^{2}$ & $\Delta R^{2}$ & $\beta$ & $R^{2}$ & $\Delta R^{2}$ \\
\hline \multicolumn{10}{|l|}{ Step 1} \\
\hline Grade point average & $.27^{* * *}$ & & & $.43^{* * *}$ & & & $.13^{*}$ & & \\
\hline Fathers' level of education & .07 & & & .01 & & & $.11^{*}$ & & \\
\hline Family income & .08 & $.10^{* * *}$ & - & .02 & $.19^{* * *}$ & - & $.14^{* *}$ & $.07^{* * *}$ & - \\
\hline \multicolumn{10}{|l|}{ Step 2} \\
\hline Perceptions of academic skills & .02 & & & $.23^{* * *}$ & & & -.05 & & \\
\hline Chances for positive outcomes & .05 & & & $-.12^{+}$ & & & .06 & & \\
\hline Educational expectations/aspirations & $.12^{*}$ & $.12^{* * *}$ & $.02^{*}$ & $.10^{+}$ & $.23^{* * *}$ & $.04^{* *}$ & $.31^{* * *}$ & $.16^{* * *}$ & $.09^{* * *}$ \\
\hline \multicolumn{10}{|l|}{ Step 3} \\
\hline Positive identification with father & $.19^{* * *}$ & $.16^{* * *}$ & $.04^{* * *}$ & .03 & $.23^{* * *}$ & .00 & .05 & $.16^{* * *}$ & .00 \\
\hline \multicolumn{10}{|l|}{ Step 4} \\
\hline $\begin{array}{l}\text { Positive Identification } \times \text { Perceptions of } \\
\text { Academic Skills }\end{array}$ & -.02 & & & .08 & & & -.04 & & \\
\hline Positive Identification $\times$ Chances for & & & & & & & & & \\
\hline Positive Outcomes & .00 & & & -.01 & & & .04 & & \\
\hline Positive Identification $\times$ Educational & & & & & & & & & \\
\hline Expectations/Aspirations & .09 & $.16^{* *}$ & .00 & $-.12^{*}$ & $.24^{* * *}$ & $.01^{+}$ & $-.11^{+}$ & $.17^{* \star *}$ & .01 \\
\hline
\end{tabular}

Note: $\beta$ weight for variable's entry into equation.

${ }^{*} p<.05 ;{ }^{* *} p<.01 ;{ }^{* * *} p<.001 ;{ }^{+} p<.10$. 
Table 3 Testing the Mediational Models Predicting Professional Career Aspirations

\begin{tabular}{|c|c|c|c|c|c|c|}
\hline \multirow[b]{2}{*}{ Predictors } & \multicolumn{3}{|c|}{$\begin{array}{l}\text { Mothers } \\
(n=413)\end{array}$} & \multicolumn{3}{|c|}{$\begin{array}{l}\text { Fathers } \\
(n=407)\end{array}$} \\
\hline & $\mathrm{B}$ & Wald & $\operatorname{Exp}(B)$ & $\mathrm{B}$ & Wald & $\operatorname{Exp}(B)$ \\
\hline \multicolumn{7}{|l|}{ Step 1} \\
\hline Grade point average & $.39^{* *}$ & 7.92 & 1.48 & $.34^{*}$ & 6.05 & 1.40 \\
\hline Child gender & $.77^{* * *}$ & 12.72 & 2.16 & $.79^{* * *}$ & 13.05 & 2.20 \\
\hline$\Delta$ Model $\chi^{2}$ & $28.56^{* * *}$ & & & $26.58^{* * *}$ & & \\
\hline \multicolumn{7}{|l|}{ Step 2} \\
\hline Perceptions of academic skills & -.11 & .41 & .90 & $.28^{+}$ & 2.80 & 1.32 \\
\hline Chances for positive outcomes & $.42^{+}$ & 3.07 & 1.53 & -.01 & .00 & .99 \\
\hline Educational expectations / aspirations $(\mathrm{P})$ & $-.21^{+}$ & 2.87 & .81 & -.11 & .84 & .90 \\
\hline Self-concept of academic skills & -.09 & .39 & .92 & -.14 & 1.07 & .87 \\
\hline School important for future & .30 & 2.05 & 1.36 & .33 & 2.39 & 1.38 \\
\hline Educational expectations / aspirations (A) & $.59^{* \star *}$ & 25.81 & 1.81 & $.58^{\star * *}$ & 26.07 & 1.79 \\
\hline$\Delta$ Model $\chi^{2}$ & $44.94^{* * *}$ & & & $42.18^{* * *}$ & & \\
\hline
\end{tabular}

Note: $\beta$ weight for variable's entry into equation. $\operatorname{Exp}(\mathrm{B})=$ estimated multiplicative change in the odds for a one-unit increase in the predictor. 1 = Male; 2 = Female. (P) and (A) refer to parent and adolescent report, respectively.

${ }^{*} p<.05 ;{ }^{* *} p<.01 ;{ }^{* * *} p<.001 ;{ }^{+} p<.10$.

sports-related beliefs and adolescents' self-concepts of their athletic ability. Three separate regression equations were estimated to test this mediational hypothesis. First, regression analyses revealed significant associations between parents' sports-related beliefs and their specific parenting practices as well as youths' values and beliefs about sports. For example, a father's perception of his child's athletic ability and talent predicted whether or not he coached a team, $\beta=$ $.14, p<.01$ and $\beta=.17, p<.01$, respectively; engaged in sports-related activities with his child, $\beta=.26, p<$ .001 and $\beta=.11, p<.05$, respectively; and offered instrumental support for his child's interests and abili- ties, $\beta=.09, p<.05$ and $\beta=.61, p<.001$, respectively. Likewise, fathers' beliefs related positively to their adolescents' athletic self-concept and the value the youth placed on sports, $\beta=.32, p<.001$, for paternal reports of youth athletic ability and the value of sports, and $\beta=.25, p<.001$, for fathers' beliefs about their children's sports talent. Comparable findings were obtained using maternal reports.

Table 4 presents the results for the final test of the mediational hypothesis for mothers and fathers. As shown, partial mediation is indicated in the model with fathers only. Fathers who viewed their children as more talented at sports, who valued athletic ability,

Table 4 Testing the Mediational Models Predicting Youths' Sports Values and Beliefs

\begin{tabular}{|c|c|c|c|c|c|c|}
\hline \multirow[b]{2}{*}{ Predictors } & \multicolumn{3}{|c|}{$\begin{array}{l}\text { Mothers } \\
(n=425)\end{array}$} & \multicolumn{3}{|c|}{$\begin{array}{l}\text { Fathers } \\
(n=405)\end{array}$} \\
\hline & $\beta$ & $R^{2}$ & $\Delta R^{2}$ & $\beta$ & $R^{2}$ & $\Delta R^{2}$ \\
\hline \multicolumn{7}{|l|}{ Step 1} \\
\hline Child gender & $-.38^{* * *}$ & $.15^{\star * *}$ & - & $-.38^{\star * *}$ & $.14^{* * *}$ & - \\
\hline \multicolumn{7}{|l|}{ Step 2} \\
\hline \multicolumn{7}{|l|}{ Values and beliefs } \\
\hline Perceptions of sports ability and value & $.37^{* \star *}$ & & & $.30^{* * *}$ & & \\
\hline Perceptions of youth sports talents & $.16^{*}$ & & & $.16^{*}$ & & \\
\hline \multicolumn{7}{|l|}{ Specific parenting behaviors } \\
\hline Involvement in coaching & - & & & .06 & & \\
\hline Sports activity involvement & .03 & & & .02 & & \\
\hline Instrumental support of sports talents & .03 & $.36^{* * *}$ & $.21^{* * *}$ & $.13^{*}$ & $.35^{* * *}$ & $.21^{* * *}$ \\
\hline
\end{tabular}

Note: $\beta$ weight for variable's entry into equation. $1=$ Male; $2=$ Female.

${ }^{*} p<.05 ;{ }^{* * *} p<.001$. 


\begin{tabular}{|c|c|c|c|c|c|c|}
\hline \multirow[b]{2}{*}{ Predictors } & \multicolumn{3}{|c|}{$\begin{array}{l}\text { Mothers } \\
(n=430)\end{array}$} & \multicolumn{3}{|c|}{$\begin{array}{l}\text { Fathers } \\
(n=409)\end{array}$} \\
\hline & $\beta$ & $R^{2}$ & $\Delta R^{2}$ & $\beta$ & $R^{2}$ & $\Delta R^{2}$ \\
\hline \multicolumn{7}{|l|}{ Step 1} \\
\hline Child gender & $-.37^{* * *}$ & $.14^{* * *}$ & - & $-.37^{* * *}$ & $.14^{* \star *}$ & - \\
\hline \multicolumn{7}{|l|}{ Step 2} \\
\hline Perceptions of sports ability and value & $.38^{* * *}$ & & & $.31^{* \star *}$ & & \\
\hline Perceptions of youth sports talents & $.19^{* * *}$ & $.35^{\star * *}$ & $.21^{* \star *}$ & $.25^{\star * *}$ & $.33^{* * *}$ & $.19^{* * *}$ \\
\hline \multicolumn{7}{|l|}{ Step 3} \\
\hline Positive identification with mother & -.05 & $.35^{* * *}$ & .00 & .01 & $.33^{* * *}$ & .00 \\
\hline \multicolumn{7}{|l|}{ Step 4} \\
\hline Positive Identification $\times$ Sports Ability and Value & .00 & & & .00 & & \\
\hline Positive Identification $\times$ Youth Sports Talents & -.06 & $.36^{* * *}$ & .01 & -.04 & $.33^{* * *}$ & .00 \\
\hline
\end{tabular}

Note: $\beta$ weight for variable's entry into equation. $1=$ Male; $2=$ Female.

${ }^{* * *} p<.001$.

and who provided higher levels of instrumental support for their children's talents had adolescents who both perceived themselves as very athletic and valued sports. Thus, in this instance, fathers' values and beliefs predicted youths' values and beliefs both directly and indirectly via their specific behaviors. In contrast, no evidence of mediation was found for mothers' specific parenting practices. Only a direct effect of mothers' sports-related beliefs on youths' values and beliefs about sports was obtained (see Table 4).

Positive identification did not moderate the association between parents' and youths' sports-related values and beliefs - a pattern consistent with the academic model. As displayed in Table 5, no significant interactions or main effects were observed for adolescent reports of positive identification with mother or father. In contrast, significant main effects were found for both mothers' and fathers' sports-related beliefs, even after controlling for gender of the adolescent. Parents who perceived their children to be talented at sports and who valued athletic ability were more likely to have adolescents who both viewed themselves as athletic and valued sports, $\Delta R^{2}=.21$ and .19 for analyses conducted with mothers and fathers, respectively.

An examination of the links between parents' values and adolescents' aspirations for a career in sports suggests that the parenting variables predicted adolescents' occupational aspirations both directly and indirectly via youths' values and beliefs about sports. A series of logistic regressions were performed using sports career aspirations as the dichotomous dependent variable. As depicted in Table 6, when adolescents' and mothers' sports-related beliefs were entered simultaneously, the relation between maternal perceptions of their children's sports talents and the children's own sports career aspirations remained significant. For each one-unit increase in mothers' perceptions of their children's talent for sports, the odds of aspiring to a career in sports increased by $38 \%$ or by a factor of 1.38 . Adolescents' beliefs about their athletic ability and the value of sports also were significant such that the odds of aspiring to a sports career increased by $74 \%$ or by a factor of 1.74 for each one-unit increase in this variable. Similar, though less robust, findings were observed with fathers, $\mathrm{B}=.38, p=.06$ (see Table 6). Taken together, these results suggest that parents' sports-related beliefs are associated with adolescents' occupational aspirations through both direct and indirect pathways.

\section{DISCUSSION}

A major question addressed by this research was whether parents' values and beliefs predict youths' values and beliefs directly or indirectly through their specific parenting practices. First, in the academic domain, parents' values and beliefs do not appear to be mediated by specific behaviors when their children are in the seventh grade. Instead, parents' role at this age is more in keeping with their roles as interpreters of reality for their children-a finding consistent with past research (e.g., Alexander \& Entwisle, 1988; Eccles, 1993; Halle et al., 1997). In contrast, fathers' behavioral investments aimed at developing their child's athletic abilities were found to partially mediate the link between parents' and youths' values and beliefs about sports. Fathers' provision of instrumental support (e.g., buying athletic equipment, attending athletic events) for their children's athletic interests and talents was a powerful mediator of this relation. Inter- 
Table 6 Testing the Mediational Models Predicting Sports Career Aspirations

\begin{tabular}{|c|c|c|c|c|c|c|}
\hline \multirow[b]{2}{*}{ Predictors } & \multicolumn{3}{|c|}{$\begin{array}{l}\text { Mothers } \\
(n=405)\end{array}$} & \multicolumn{3}{|c|}{$\begin{array}{l}\text { Fathers } \\
(n=424)\end{array}$} \\
\hline & $\beta$ & Wald & $\operatorname{Exp}(B)$ & B & Wald & $\operatorname{Exp}(B)$ \\
\hline \multicolumn{7}{|l|}{ Step 1} \\
\hline Child gender & $1.31^{* * *}$ & 18.53 & 3.74 & $1.31^{* * *}$ & 18.18 & 3.69 \\
\hline Ethnicity & $-.44^{*}$ & 5.49 & .64 & $-.38^{*}$ & 4.02 & .68 \\
\hline$\Delta$ Model $\chi^{2}$ & $40.40^{* * *}$ & & & $37.27^{* * *}$ & & \\
\hline \multicolumn{7}{|l|}{ Step 2} \\
\hline Perceptions of sports ability and value & .02 & .01 & 1.02 & $.38^{+}$ & 2.80 & 1.47 \\
\hline Perceptions of sports talents & $.33^{* *}$ & 8.60 & 1.38 & $.36^{* *}$ & 6.77 & 1.44 \\
\hline Self-concept of sports ability and value & $.55^{\star}$ & 6.17 & 1.74 & $.38^{+}$ & 3.49 & 1.46 \\
\hline$\Delta$ Model $\chi^{2}$ & $30.21^{* * *}$ & & & $26.36^{* * *}$ & & \\
\hline
\end{tabular}

Note: $\beta$ weight for variable's entry into equation. $\operatorname{Exp}(\mathrm{B})=$ estimated multiplicative change in the odds for a one-unit increase in the predictor. 1 = Male; 2 = Female. $1=$ African American; 2 = European American.

${ }^{*} p<.05 ;{ }^{* *} p<.01 ;{ }^{* * *} p<.001 ;{ }^{+} p<.10$.

estingly, this pattern of associations was not observed with mothers. The special role of fathers in children's socialization into sports has been documented elsewhere (e.g., Lewko \& Greendorfer, 1988).

Why might fathers' specific behaviors serve to partially mediate the link between parents' and adolescents' values and beliefs about sports, but not about academics? One possibility is that parents are less likely to engage in proactive practices such as helping their children with homework by the time adolescents enter junior high or middle school. This interpretation is congruent with evidence from other studies indicating a dramatic decline in parental involvement in children's schooling as youth move into early adolescence (Dornbusch \& Ritter, 1988; Eccles \& Harold, 1996; Stevenson \& Baker, 1987). Parents may assume that children at this age need and desire a certain amount of autonomy with respect to their schoolwork. Moreover, they may feel less equipped to help out with assignments as the work becomes increasingly complex (Eccles \& Harold, 1996). In short, parents may no longer believe that their behavioral involvement is important or useful when it comes to academics. Indeed, a high level of school involvement might signify a reaction on the part of parents to a child having academic difficulties rather than an active promotion of academics. Nonetheless, parents send clear messages concerning the value of education and their beliefs about their children's academic potential regardless of their level of involvement. Other contexts beyond the family, such as the school or peer group, may also begin to assume a larger role in socializing adolescents around academic pursuits.
In contrast, for children to value athletics and want to pursue a career in sports, fathers' specific parenting practices do matter. Despite possibly wanting their "space" from parents, teens at this age may still benefit from parents being actively involved in sports. Unlike academics, fostering an athletic talent typically requires parents to purchase sports equipment and to shuttle their children back and forth to practices and games. In keeping with evidence that paternal involvement in particular shapes children's instrumental competencies (see Parke, 1996), this study's findings suggest that fathers, through their provision of support for their children's athletic interests and talents, may fill a vacuum not covered by other developmental contexts. Taking a physical education class in school might not carry the same message as playing "catch" with your father or having him come to your basketball game. Such behavioral reinforcement might serve as an important source of role modeling and reinforcement without which adolescents are less likely to seek out a sports niche (Czikszentmihalyi, Rathunde, \& Whalen, 1993). One implication is that observing an attachment figure engage in sportsrelated behaviors represents a key mechanism for orienting young adolescents toward athletics. At least for sports, this appears to be especially true for fathers of both sons and daughters. Similar processes might operate in other activity domains (e.g., music, art) that require a behavioral commitment on the part of parents (Bloom, 1985).

Contrary to expectations, positive identification with parents did not moderate the relation between parents' and adolescents' values and beliefs in either 
the academic or the sports domain. Nonetheless, positive identification was directly related to youths' values and beliefs about academics. Adolescents who strongly identified with their mothers in particular placed a greater emphasis on school as important to their future, and possessed higher levels of academic self-efficacy and educational expectations / aspirations. In contrast, in the sports domain, higher levels of positive identification were not associated with adolescents who viewed themselves as athletic and who valued sports. Mothers' and fathers' sports-related values and beliefs alone appeared to be the important predictors of youths' own values and beliefs about sports. That positive identification did not moderate the transmission of values from parents to children may reflect the fact that early adolescents are close to the peak of differentiating themselves from parents rather than identifying with them. Over time, the degree to which children positively identify with their parents may modify the likelihood of internalizing parental achievement-related values and beliefs.

Finally, parents' values and beliefs predicted adolescents' occupational aspirations via both direct and indirect pathways; however, the pattern of relations differed across achievement domains. For example, in the academic model, relations between maternal beliefs about positive outcomes and adolescents' aspirations for a professional career were mediated by youths' educational expectations and aspirations. Teens who possessed higher educational expectations and aspirations were more likely to desire a professional career in the future. In comparison, mothers' and fathers' sports-related beliefs predicted youths' aspirations for athletic careers directly, as well as indirectly through adolescents' own sports-related beliefs. Adolescents who perceived themselves as athletic and valued sports, and whose parents believed that they were talented at sports, were more likely to see themselves as professional sports figures in the future.

By this age, adolescents' academic self-perceptions and expectations about their educational futures have become relatively crystallized and stable (Eccles et al., 1989). Consequently, parents may no longer exert a strong, direct influence on their children's occupational aspirations. Instead, significant others outside the family, such as teachers or coaches, may have a greater direct impact on adolescents' occupational aspirations as a source of new information on potential long-term career options. Findings from other studies with younger children suggest that parents exert stronger effects on children's academic selfperceptions and educational expectations during the elementary school years (for a review, see Eccles et al., 1997). This relation is likely to be fully mediated by early adolescence when parents are typically no longer actively involved with their children's academic activities (Dornbusch \& Ritter, 1988; Eccles \& Harold, 1996; Stevenson \& Baker, 1987). In contrast, a direct effect of parents' sports-related values and beliefs on youths' athletic aspirations may still be apparent because early adolescents' own values and beliefs about sports are less crystallized, and parents still play an active role in their children's athletic activities.

Subgroup analyses revealed a similar pattern of findings across African American and European American males and females. The lack of group differences in the patterns of relations among variables is particularly interesting in light of gender and race differences in the percentages of adolescents aspiring to professional or sports careers. For example, more European American than African American male adolescents aspired to sports careers (21\% versus $11.8 \%$, respectively), and relatively few female adolescents wanted to pursue a career in sports (less than 3\%). Approximately one half of females and less than one third of males across both races aspired to professional occupations. Despite these differences in the numbers of adolescents aspiring to either sports or professional jobs, with few exceptions, this study's findings suggest that the processes of socialization linking dimensions of parenting to adolescents' occupational aspirations are comparable across groups. This is especially important, given the unique nature of the sample, in that race and income were not confounded in the present study. Not only did parents matter with respect to career development, but the ways in which they mattered appear to be similar for African Americans and European Americans alike. The pattern of relations among these variables may be different among single-parent families and stepfamilies. Future research needs to address this possibility using more sophisticated models that incorporate both mothers and fathers as part of a complex family system.

A major shortcoming of this study is its crosssectional design. Although our conceptual model posits relations among variables that operate in certain directions (i.e., parents influence children), a number of alternative explanations are possible that account for the effects of "third variables" and bidirectional relations. Equally viable is a model in which the effects are partially child driven (R. O. Bell, 1979). For example, children's own self-perceptions and the value they place on various activities may influence parental values and expectations and, ultimately, their parents' behaviors. Longitudinal analyses are clearly needed to disentangle the causal pathways through which parents influence adolescents' visions of themselves in the future. The processes linking parents' 
achievement-related values and beliefs to adolescents' occupational aspirations may well represent reciprocal influences.

An additional caveat concerns the validity of some of the measures, especially occupational aspirations. Designed to capture the self-images that adolescents project into the future, the coding scheme made no allowance for how realistic or fantasy based these occupational aspirations may have been, given that the adolescents in question were seventh graders. From a conceptual standpoint, however, the goal of this study was to identify the types of futures the adolescents imagined for themselves at this time point. We argue that these visions - no matter how fantastic - are important markers of the teens' current state of mind with respect to career development.

In the present study, two domain-specific modelsan academic and a sports model - were developed to explore the pathways linking parents' beliefs and practices to early adolescents' occupational aspirations. Few researchers have examined how parents, especially fathers, socialize adolescents' achievementrelated values and beliefs, and vocational goals beyond the realm of academics (Wigfield \& Eccles, 1992). Congruent with both theory (e.g., Eccles et al., 1983; Holland, 1985; Super, 1990) and empirical research (e.g., Eccles et al., 1998; Mortimer et al., 1986), this study lends credence to the primacy of the family as an important context for career development. Despite some clear limitations, these results highlight a few processes by which parents might shape their children's career aspirations during early adolescence-a potentially critical period when individuals' emerging self-concepts begin to influence later occupational planning for the future (Super, 1990).

\section{ACKNOWLEDGMENTS}

This research was supported by a grant from the MacArthur Foundation Research Network on Successful Adolescent Development Among Youth in High-Risk Settings awarded to Jacquelynne S. Eccles. The authors would like to thank Todd Bartko, Elaine Belansky, Diane Early, Kari Fraser, Ariel Kalil, Linda Kuhn, Karen McCarthy, Leslie Morrison, Stephen Peck, Dairia Ray, Kate Rosenblum, Robert Roeser, Sherri Steele, Erica Taylor, Cindy Winston, and Carol Wong.

\section{ADDRESSES AND AFFILIATIONS}

Corresponding author: Kathleen M. Jodl, Gender and Achievement Research Program, University of Michigan, 204 South State Street, Ann Arbor, MI 481091290; e-mail: jodlkm@umich.edu. Alice Michael, Oksana Malanchuk, Jacquelynne Eccles, and Arnold Sameroff are also at the University of Michigan.

\section{APPENDIX A}

Summary of Measures and Items

Youths' Values, Beliefs, and Expectations Academic self-concept

Value of education for future

Educational expectations/aspirations
Compared with other kids your age, how well do you do in math?

$1=$ much worse, $7=$ much better

Compared with other kids your age, how well do you do in other school subjects?

$(1=$ much worse, $7=$ much better $)$

How good are you in math?

$(1=$ not at all good, $7=$ very good $)$

How good are you in other school subjects?

$(1=$ not at all good, $7=$ very good $)$

I have to do well in school if I want to be a success in life.

$(1=\text { strongly agree, } 5=\text { strongly disagree })^{\text {a }}$

Even if I do well in school, I still won't be able to get a good job when I grow up.

( 1 = strongly agree, $5=$ strongly disagree)

Schooling is not so important for kids like me.

( 1 = strongly agree, $5=$ strongly disagree $)$

I learn more useful things from friends and relatives than I learn in school.

$(1=$ strongly agree, $5=$ strongly disagree $)$

I have so much to do at home that I don't have enough time to do homework.

$(1=$ strongly agree, $5=$ strongly disagree)

How far would you like to go in school?

$(1=$ less than eighth grade, 7 = J.D., M.D., Ph.D. $)$

How far will you actually go in school?

$(1=$ less than eighth grade, 7 = J.D., M.D., Ph.D. $)$ 
Jodl et al. 1261

APPENDIX A Continued

Items

$\alpha$

Sports self-concept and value

Parents' Values, Beliefs, and Expectations ${ }^{\mathrm{b}}$ Chances for positive youth outcomes

Educational expectations / aspirations for youth

Perceptions of youth's academic ability

Perceptions of youth's sports ability and value

Perceptions of youth's talent for sports (open-ended item)

Specific parenting behaviors ${ }^{b}$

Academic activity involvement

Instrumental support of academic talents (open-ended item)

Involvement in youth's school (count of "yes" responses)

Sports activity involvement

Instrumental support of sport talents Coaching (fathers only)

Positive identification with mother $/$ father $^{b}$
Compared with other kids your age, how well do you do in sports?

.88

$(1=$ much worse, $7=$ much better $)$

How good are you in sports?

$(1=$ not at all good, $7=$ very good $)$

Compared with other kids your age, how important are sports to you?

$(1=$ much less, $7=$ much more $)$

What are the chances your seventh grader will complete college?

$.81 / .79$

( 1 = very low, 5 = very high)

What are the chances your seventh grader will find a stable and well-paying

job when $\mathrm{s} /$ he becomes an adult?

(1 = very low, 5 = very high)

What are the chances your seventh grader will do well in junior and senior

high school?

(1 = very low, 5 = very high)

How far would you like your child to go in school?

( 1 = less than eighth grade, 7 = J.D., M.D., Ph.D.)

How far do you think your child will go in school?

(1 = less than eighth grade, 7 = J.D., M.D., Ph.D.)

Compared with other children, how well do you think your child will do in math?

( 1 = much worse, $7=$ much better)

Compared with other children, how well do you think your child will do in other

schoolwork?

( $1=$ much worse, $7=$ much better $)$

How good is your child in math?

$(1=$ not at all good, $7=$ very good $)$

How good is your child in other schoolwork?

$(1=$ not at all good, $7=$ very good $)$

Compared with other children, how well do you think your child will do in sports?

( 1 = much worse, $7=$ much better $)$

How good is your child at sports? $(1=$ not at all good, $7=$ very good $)$

How important is it to you that your child does well in sports?

( $1=$ not at all important, $7=$ very important $)$

Does your child have any special [sports] talents, skills, or interests?

Please list those [sports] talents.

In the last month, how often have you helped your seventh grader do homework or a school project?

$(1=$ not at all, $6=$ more than once a day)

In the last month, how often have you asked your seventh grader what $\mathrm{s} / \mathrm{he}$ did at school?

( $1=$ not at all, $6=$ more than once a day)

What have you done to help your child get better at [academic] talent?

N.A.

Have you done fund-raising for the PTA this year?

Have you helped the teacher in the classroom or on class trips this year?

Have you helped in the library, cafeteria, playground or office this year?

Have you done something else [at school]?

In the last month, how often have you played sports with your 7 th grader?

( $1=$ not at all, $6=$ more than 1 hour a day)

What have you done to help your child get better at [sport] talent?

For which [sport] activities have you been the coach/leader?

How much do you want to be like the kind of person your mother (father) is when you are an adult?

$(1=$ not at all, $4=$ a lot $)$

How close do you feel to your mother (father)?

$(1=$ not at all, $4=$ a lot $)$
N.A.

N.A.

N.A.

N.A.

$.60 / .68$

Note: N.A. = not applicable.

a Item was reverse coded.

${ }^{b}$ Alphas in this section are reported as mother/father. 


\section{APPENDIX B}

Table B1 Intercorrelations among Variables for the Academic Model

\begin{tabular}{|c|c|c|c|c|c|c|c|c|c|c|c|c|c|c|c|c|c|c|}
\hline Variable & 1 & 2 & 3 & 4 & 5 & 6 & 7 & 8 & 9 & 10 & 11 & 12 & 13 & 14 & 15 & 16 & 17 & 18 \\
\hline \multicolumn{19}{|l|}{ 1. Professional career aspirations $(\mathrm{Y})$} \\
\hline 2. Academic self-concept $(\mathrm{Y})$ & $.10^{*}$ & & & & & & & & & & & & & & & & & \\
\hline 3. Value of school for future $(\mathrm{Y})$ & $.16^{* *}$ & $.33^{* \star *}$ & & & & & & & & & & & & & & & & \\
\hline 4. Educational expectations / aspirations $(\mathrm{Y})$ & $.32^{* * *}$ & $.29^{\star * \star}$ & $.25^{\star * *}$ & & & & & & & & & & & & & & & \\
\hline 5. Chances for positive outcomes (M) & $.20^{\star * *}$ & $.31^{* * *}$ & $.31^{* * *}$ & $.34^{* * *}$ & & & & & & & & & & & & & & \\
\hline 6. Chances for positive outcomes $(\mathrm{F})$ & $.15^{\star *}$ & $.22^{\star \star *}$ & $.23^{* \star *}$ & $.25^{\star * *}$ & $.42^{* \star *}$ & & & & & & & & & & & & & \\
\hline 7. Educational expectations/aspirations (M) & $.12^{* *}$ & $.19^{* * *}$ & $.24^{* * *}$ & $.45^{\star * *}$ & $.52^{\star * *}$ & $.40^{\star * *}$ & & & & & & & & & & & & \\
\hline 8. Educational expectations/aspirations (F) & $.13^{* *}$ & $.22^{\star * *}$ & $.23^{* * *}$ & $.37^{* * *}$ & $.41^{* * *}$ & $.50^{\star \star *}$ & $.56^{* * *}$ & & & & & & & & & & & \\
\hline 9. Youth's academic ability (M) & $.16^{* *}$ & $.47^{\star \star \star}$ & $.29^{* \star *}$ & $.29^{\star \star *}$ & $.59^{* \star *}$ & $.44^{* \star *}$ & $.35^{\star * *}$ & $.27^{* \star *}$ & & & & & & & & & & \\
\hline 10. Youth's academic ability $(\mathrm{F})$ & $.18^{* * *}$ & $.39^{* * *}$ & $.23^{* \star *}$ & $.20^{\star * *}$ & $.49^{* * *}$ & $.63^{* * *}$ & $.36^{* * *}$ & $.42^{\star \star \star}$ & $.64^{\star \star *}$ & & & & & & & & & \\
\hline 11. Academic activity involvement (M) & -.04 & -.01 & .09 & .06 & $.10^{*}$ & $.10^{*}$ & $.19^{* * *}$ & $.15^{\star *}$ & .09 & .06 & & & & & & & & \\
\hline 12. Academic activity involvement $(\mathrm{F})$ & -.05 & .06 & .09 & .05 & $.11^{*}$ & $.17^{* \star *}$ & $.10^{*}$ & $.21^{* * *}$ & .06 & $.13^{* *}$ & $.26^{* * *}$ & & & & & & & \\
\hline 13. Academic instrumental support (M) & .05 & $.19^{* * *}$ & $.13^{* *}$ & .09 & $.16^{* *}$ & $.16^{* *}$ & $.15^{\star *}$ & $.16^{\star *}$ & $.22^{* * *}$ & $.16^{* *}$ & .02 & .00 & & & & & & \\
\hline 14. Academic instrumental support (F) & -.09 & $.14^{* *}$ & .02 & .03 & .09 & $.13^{* *}$ & $.13^{* *}$ & $.18^{* * *}$ & $.13^{* *}$ & $.14^{* *}$ & $.10^{*}$ & $.17^{* * *}$ & $.10^{*}$ & & & & & \\
\hline 15. School involvement $(\mathrm{M})$ & .03 & $.10^{*}$ & .01 & $.10^{*}$ & $.20^{* * *}$ & .07 & $.20^{* * *}$ & $.13^{* *}$ & $.19^{* *}$ & $.11^{*}$ & $.16^{* *}$ & $.10^{*}$ & .07 & $.12^{*}$ & & & & \\
\hline 16. School involvement $(\mathrm{F})$ & .02 & -.03 & -.04 & .02 & .01 & $.10^{*}$ & .08 & .06 & -.01 & .06 & .08 & $.13^{* *}$ & -.02 & .00 & .04 & & & \\
\hline 17. Positive identification with mother $(\mathrm{Y})$ & .07 & $.16^{* *}$ & $.25^{* * *}$ & $.16^{* *}$ & .04 & .07 & .07 & .03 & .08 & .03 & $.16^{* *}$ & .06 & .05 & -.07 & .07 & .03 & & \\
\hline 18. Positive identification with father $(\mathrm{Y})$ & .04 & .09 & $.21^{* * *}$ & .09 & .08 & .07 & $.11^{*}$ & $.11^{*}$ & .07 & .05 & $.12^{*}$ & $.18^{\star * *}$ & -.06 & .02 & .06 & .08 & $.57^{* * *}$ & \\
\hline$S D$ & .49 & 1.00 & .59 & 1.35 & .66 & .71 & 1.18 & 1.21 & .97 & 1.00 & .96 & .98 & 2.08 & 1.65 & .79 & 1.28 & .62 & .67 \\
\hline
\end{tabular}

Note: $N=444 .(\mathrm{M}),(\mathrm{F})$, and $(\mathrm{Y})$ refer to mother, father, and youth report, respectively.

${ }^{*} p<.05 ;{ }^{* *} p<.01$; ${ }^{* * *} p<.001$. 


\section{Table B2 Intercorrelations among Variables for the Sports Model}

\begin{tabular}{|c|c|c|c|c|c|c|c|c|c|c|c|c|c|}
\hline Variable & 1 & 2 & 3 & 4 & 5 & 6 & 7 & 8 & 9 & 10 & 11 & 12 & 13 \\
\hline \multicolumn{14}{|l|}{ 1. Sports career aspirations $(\mathrm{Y})$} \\
\hline 2. Sports self-concept and value $(\mathrm{Y})$ & $.18^{* * *}$ & & & & & & & & & & & & \\
\hline 3. Youth sports ability and value (M) & $.10^{*}$ & $.45^{\star * *}$ & & & & & & & & & & & \\
\hline 4. Youth sports ability and value (F) & $.14^{* *}$ & $.43^{* * *}$ & $.48^{\star * *}$ & & & & & & & & & & \\
\hline 5. Youth talent for sports $(\mathrm{M})$ & $.24^{* * *}$ & $.36^{* * *}$ & $.28^{* * *}$ & $.26^{* * *}$ & & & & & & & & & \\
\hline 6. Youth talent for sports $(\mathrm{F})$ & $.25^{\star \star *}$ & $.42^{* * *}$ & $.31^{* * *}$ & $.29^{\star * *}$ & $.43^{* * *}$ & & & & & & & & \\
\hline 7. Sport activity involvement (M) & $.10^{*}$ & $.22^{* * *}$ & $.25^{* * *}$ & $.13^{* *}$ & $.19^{* * *}$ & $.18^{* * *}$ & & & & & & & \\
\hline 8. Sport activity involvement $(\mathrm{F})$ & $.10^{*}$ & $.24^{* * *}$ & $.19^{* * *}$ & $.28^{* * *}$ & $.17^{* * *}$ & $.22^{* * *}$ & $.34^{* * *}$ & & & & & & \\
\hline 9. Instrumental support of sports (M) & $.20^{\star * *}$ & $.32^{* * *}$ & $.27^{* * *}$ & $.24^{* * *}$ & $.83^{* * *}$ & $.41^{* * *}$ & $.19^{* \star *}$ & $.14^{\star *}$ & & & & & \\
\hline 10. Instrumental support of sports (F) & $.19^{\star * *}$ & $.38^{* * *}$ & $.25^{* * *}$ & $.26^{* * *}$ & $.28^{* * *}$ & $.68^{* * *}$ & $.22^{* * *}$ & $.19^{\star * *}$ & $.28^{\star * *}$ & & & & \\
\hline 11. Coaching $(\mathrm{F})$ & $.16^{* *}$ & $.23^{* * *}$ & $.16^{* *}$ & $.17^{\star * *}$ & $.18^{* * *}$ & $.26^{* * *}$ & $.27^{* * *}$ & $.25^{\star * *}$ & $.18^{* * *}$ & $.28^{* * *}$ & & & \\
\hline 12. Positive identification with mother $(\mathrm{Y})$ & $-.12^{*}$ & -.03 & $.10^{*}$ & .03 & -.06 & -.04 & .08 & $.11^{*}$ & -.01 & -.09 & -.02 & 13. & \\
\hline 13. Positive identification with father $(\mathrm{Y})$ & -.03 & $.10^{*}$ & $.12^{*}$ & .06 & .03 & .06 & $.11^{*}$ & $.17^{* * *}$ & .02 & .00 & .08 & $.57^{* * *}$ & \\
\hline$S D$ & .32 & 1.63 & 1.22 & 1.21 & 1.59 & 1.46 & 1.94 & 2.14 & 1.11 & 1.14 & 1.60 & .62 & .67 \\
\hline
\end{tabular}

Note: $N=444 .(\mathrm{M}),(\mathrm{F})$, and $(\mathrm{Y})$ refer to mother, father, and youth report, respectively.

${ }^{*} p<.05 ;{ }^{* *} p<.01$; ${ }^{* *} p<.001$. 


\section{REFERENCES}

Alexander, K. L., \& Entwisle, D. R. (1988). Achievement in the first two years of school: Patterns and processes. Monographs of the Society for Research in Child Development, 53(2, Serial No. 218).

Baron, R. M., \& Kenny, D. A. (1986). The moderatormediator variable distinction in social psychological research: Conceptual, strategic, and statistical considerations. Journal of Personality and Social Psychology, 51, 1173-1182.

Bell, K., Allen, J. P., Hauser, S. T., \& O'Connor, T. G. (1996). Family factors and young adult transitions: Educational attainment and occupational prestige. In J. A. Graber, J. Brooks-Gunn, \& A. C. Petersen (Eds.), Transitions through adolescence: Interpersonal domains and contexts (pp. 345-366). Mahwah, NJ: Erlbaum.

Bell, R. O. (1979). Parent, child and reciprocal influences. American Psychologist, 34, 821-826.

Betz, N. E., \& Fitzgerald, L. F. (1987). The career psychology of women. Orlando, FL: Academic Press.

Betz, N. E., \& Hackett, G. (1986). Applications of self-efficacy theory to understanding career choice behavior. Journal of Social and Clinical Psychology, 4, 279-289.

Bloom, B. S. (1985). Developing talent in young people. New York: Ballantine Books.

Blustein, D. L., Walbridge, M. M., Friedlander, M. L., \& Palladino, D. E. (1991). Contributions to psychological separation and parental attachment to the career development process. Journal of Counseling Psychology, 38, 39-50.

Cook, T. D., Habib, F., Phillips, M., Settersten, R. A., Shagle, S. C., \& Degirmencioglu, S. M. (1999). Comer's School Development Program in Prince George's County: A theory-based evaluation. American Educational Research Journal, 36, 543-597.

Czikszentmihalyi, M., Rathunde, K., \& Whalen, S. (1993). Talented teenagers: The roots of success and failure. New York: Cambridge University Press.

Dauber, S. L., \& Epstein, J. L. (1993). Parents' attitudes and practices of involvement in inner-city elementary and middle schools. In N. F. Chavkin (Ed.), Families and schools in a pluralistic society (pp. 53-71). Albany, NY: SUNY Press.

Deeter, T. E. (1990). Re-modeling expectancy and value in physical activity. Journal of Sport and Exercise Psychology, $12,86-91$.

Dornbusch, S. M., \& Ritter, P. L. (1988). Parents of high school students: A neglected resource. Educational Horizons, 66, 75-77.

Dornbusch, S. M., Ritter, P. L., Leiderman, L. P., Roberts, D. F., \& Fraleigh, M. J. (1987). The relation of parenting style to adolescent school performance. Child Development, 58, 1244-1257.

Eccles, J. S. (1983). Expectancies, values and academic behaviors. In J. T. Spence (Ed.), The development of achievement motivation (pp. 283-331). Greenwich, CT: JAI.

Eccles, J. S. (1993). School and family effects on the ontogeny of children's interests, self-perceptions, and activity choices. In R. Dienstbier \& J. E. Jacobs (Eds.), Developmental perspectives on motivation (Vol. 40, pp. 145-208). Lincoln: University of Nebraska Press.

Eccles, J., Adler, T. F., Futterman, R., Goff, S. B., Kaczala, C. M., Meece, J. L., \& Midgley, C. (1983). Expectations, values and academic behaviors. In J. T. Spence (Ed.), Achievement and achievement motivation (pp. 283-331). San Francisco: W. H. Freeman.

Eccles, J., Adler, T. F., \& Kaczala, C. M. (1982). Socialization of achievement attitudes and beliefs: Parental influences. Child Development, 53, 310-321.

Eccles, J. S., Barber, B., \& Jozefowicz, D. H. (1998). Linking gender to educational, occupational, and recreational choices: Applying the Eccles et al. model of achievementrelated choices. In W. B. Swann, J. H. Langlois, \& L. A. Gilbert (Eds.), The many faces of gender: The multidimensional model of Janet Spence. Washington, DC: APA Press.

Eccles, J. S., \& Harold, R. D. (1991). Gender differences in sport involvement: Applying the Eccles' expectancyvalue model. Journal of Applied Sport Psychology, 3, 7-35.

Eccles, J. S., \& Harold, R. D. (1996). Family involvement in children's and adolescents' schooling. In A. Booth (Ed.), Family-school links: How do they affect educational outcomes? (pp. 3-34). Mahwah, NJ: Erlbaum.

Eccles, J. S., Wigfield, A., Flanagan, C. A., Miller, C., Reuman, D. A., \& Yee, D. (1989). Self-concepts, domain values, and self-esteem: Relations and changes at early adolescence. Journal of Personality, 57, 283-310.

Eccles, J. S., Wigfield, A., Harold, R., \& Blumenfeld, P. (1993). Age and gender differences in children's self- and task perceptions during elementary school. Child Development, 64, 830-847.

Eccles, J. S., Wigfield, A., \& Schiefele, U. (1997). Motivation to succeed. In N. Eisenberg (Ed.), W. Damon (Series Ed.), Handbook of child psychology: Vol 3. (5th ed., pp. 1017-1095). New York: Wiley.

Fitzgerald, L. F., \& Betz, N. E. (1983). Issues in the vocational psychology of women. In W. B. Walsh \& S. H. Osipow (Eds.), Handbook of vocational psychology: Vol. 1. Foundations (pp. 83-159). Hillsdale, NJ: Erlbaum.

Forehand, R., Long, N., Brody, G., \& Fauber, R. (1986). Home predictors of young adolescents' school behavior and academic performance. Child Development, 57, 1528-1533.

Ginzberg, E. (1972). Toward a theory of occupational choice: A restatement. Vocational Guidance Quarterly, 20, 169-176.

Grotevant, H. D., \& Cooper, C. R. (1988). The role of family experience in career exploration: A lifespan perspective. In P. B. Baltes, D. C. Featherman, \& R. M. Lerner (Eds.), Lifespan development and behavior, Vol. 8. Hillsdale, NJ: Erlbaum.

Halle, T. G., Kurtz-Costes, B., \& Mahoney, J. L. (1997). Family influences on school achievement in low-income, African-American children. Journal of Educational Psychology, 89, 527-537.

Hannah, J. S., \& Kahn, S. E. (1989). The relationship of socioeconomic status and gender to the occupational choices of grade 12 students. Journal of Vocational Behavior, 34, 161-178.

Hill, M. S., \& Duncan, G. (1987). Parental family income and 
the socioeconomic attainment of children. Social Science Research, 16, 39-73.

Holland, J. L. (1985). Making vocational choices: A theory of vocational personalities and work environments (2nd ed.). Englewood Cliffs, NJ: Prentice-Hall.

Hollinger, C. L. (1983). Self-perception and the career aspirations of mathematically talented female adolescents. Journal of Vocational Behavior, 22, 49-62.

Hoyle, R. H., \& Leff, S. S. (1997). The role of parental involvement in youth sport participation and performance. Adolescence, 32, 237-243.

Jackson, R. M., \& Meara, N. M. (1977). Father identification, achievement, and occupational behavior of rural youth: 5-year follow-up. Journal of Vocational Behavior, 10, 82-91.

Klebanov, P., \& Brooks-Gunn, J. (1992). Impact of maternal attitudes, girls' adjustment, and cognitive skills upon academic performance in middle and high school. Journal of Research on Adolescence, 2, 81-102.

Lent, R. W., Brown, S. D., \& Hackett, G. (1994). Toward a unifying social cognitive theory of career and academic interest, choice, and performance. Journal of Vocational Behavior, 45, 79-122.

Lewko, J. H., \& Greendorfer, S. L. (1988). Family influences in sport socialization of children and adolescents. In F. L. Smoll, R. A. Magill, \& M. J. Ash (Eds.), Children in sport (3rd ed., pp. 287-300). Champaign, IL: Human Kinetics.

Lunneborg, P. W. (1982). Role model influencers of nontraditional professional women. Journal of Vocational Behavior, 20, 276-281.

MacKay, W. R., \& Miller, C. A. (1982). Relations of socioeconomic status and sex variables to the complexity of worker functions in the occupational choices of elementary school children. Journal of Vocational Behavior, 20, 31-39.

Masselam, V. S., Marcus, R. F., \& Stunkard, C. L. (1990). Parent-adolescent communication, family functioning, and school performance. Adolescence, 25, 725-737.

Miller, S. A., Manhal, M., \& Mee, L. L. (1991). Parental beliefs, parental accuracy, and children's cognitive performance: A search for causal relations. Developmental Psychology, 27, 267-276.

Mortimer, J. T., \& Kumka, D. S. (1982). A further examination of the "occupational linkage hypothesis." Sociological Quarterly, 23, 3-16.

Mortimer, J. T., Lorence, J., \& Kumka, D. S. (1986). Work, family, and personality: Transition to adulthood. Norwood, NJ: Ablex.

Muller, C., \& Kerbow, D. (1993). Parent involvement in the home, school, and community. In B. Schneider \& J. S. Coleman (Eds.), Parents, their children, and schools (pp. 13-42). Boulder, CO: Westview Press.
Palmer, S., \& Cochran, L. (1988). Parents as agents of career development. Journal of Counseling Psychology, 35, 71-76.

Parke, R. D. (1996). Fatherhood. Cambridge, MA: Harvard University Press.

Penick, N. I., \& Jepsen, D. A. (1992). Family functioning and adolescent career development. The Career Development Quarterly, 40, 208-222.

Phillips, D. A. (1987). Socialization of perceived academic competence among highly competent children. Child Development, 58, 1308-1320.

Ridgeway, C. (1978). Parental identification and patterns of career orientation in college women. Journal of Vocational Behavior, 12, 1-11.

Roberts, G. C., \& Duda, J. L. (1984). Motivation in sport: The mediating role of perceived ability. Journal of Sport Psychology, 6, 312-324.

Roe, A. (1957). Early determinants of vocational choice. Journal of Counseling Psychology, 4, 212-217.

Scanlan, T. K., \& Lewthwaite, R. (1985). Social psychological aspects of competition for male youth sport participants: III. Determinants of personal performance expectancies. Journal of Sport Psychology, 7, 389-399.

Scanlan, T. K., \& Lewthwaite, R. (1986). Social psychological aspects of competition for male youth sport participants: IV. Predictors of enjoyment. Journal of Sport Psychology, 8, 25-35.

Schulenberg, J. E., Vondracek, F. W., \& Crouter, A. C. (1984). The influence of the family on vocational development. Journal of Marriage and the Family, 46, 129-143.

Stevenson, D. L., \& Baker, D. P. (1987). The family-school relation and the child's school performance. Child Development, 58, 1348-1357.

Super, D. E. (1990). A life-span, life-space approach to career development. In D. Brown \& L. Brooks (Eds.), Career choice and development: Applying contemporary theories to practice (pp. 197-261). San Francisco, CA: Jossey-Bass.

Trent, L. M., Cooney, G., Russell, G., \& Thornton, P. M. (1996). Significant others' contribution to early adolescents' perceptions of their competence. British Journal of Educational Psychology, 66, 95-107.

Trusty, J. (1996). Family influences on educational expectations of late adolescents. The Journal of Educational Research, 91, 260-270.

Weiss, M. R. (1987). Self-esteem and achievement in children's sport and physical activity. In D. Gould \& M. R. Weiss (Eds.), Advances in pediatric sport sciences: Vol. 2. Behavioral issues. Champaign, IL: Human Kinetics.

Wigfield, A., \& Eccles, J. S. (1992). The development of achievement task values: A theoretical analysis. Developmental Review, 12, 265-310.

Wilson, P. M., \& Wilson, J. R. (1992). Environmental influences on adolescent educational aspirations. Youth $\mathcal{E}$ Society, 24, 52-70. 